Aldona Standar

Uniwersytet Przyrodniczy w Poznaniu

\title{
Realizacja wydatków inwestycyjnych a kondycja finansowa JST. Przykład gmin wiejskich województwa wielkopolskiego ${ }^{1}$
}

\section{IMPLEMENTATION OF INVESTMENT EXPENDITURES VERSUS FINANCIAL CONDITION OF LOCAL GOVERNMENTS AN EXAMPLE OF RURAL COMMUNES IN THE WIELKOPOLSKA PROVINCE}

\begin{abstract}
Celem badania było sprawdzenie zależności pomiędzy kondycja finansowa a realizacja wydatków inwestycyjnych na przykładzie gmin wiejskich województwa wielkopolskiego. $W$ pierwszej części przedstawiono ksztaltowanie się badanego wskaźnika wydatków inwestycyjnych na mieszkańca uwzględniajac miary statystyki opisowej. Następnie pogrupowano gminy wedtug badanej miary $i$ porównano z syntetycznym miernikiem kondycji finansowej. Kolejno zbadano zależność pomiędzy tymi miarami, a wynik świadczacy o jej wystapieniu stat się podstawa dalszej analizy. Ustalono, że to gminy o najkorzystniejszej sytuacji finansowej zrealizowaty największe inwestycje, których wynik byt statystycznie istotnie wyższy niż pozostatych grup JST. W ostatniej części udowodniono, że wspomniana zależność występuje również pomiędzy analizowanym wskaźnikiem wydatków inwestycyjnych a zmiennymi finansowymi świadczqcymi o kondycji finansowej gmin.
\end{abstract}

Słowa kluczowe: analiza wariancji, JST, kondycja finansowa, metoda TOPSIS, wydatki inwestycyjne.

\section{Wprowadzenie}

Władze jednostek samorządu terytorialnego w celu zapewnienia rozwoju gospodarczego na swoim terenie, muszą realizować inwestycje ${ }^{2}$. Ich zakres wynika $z$ określonych przez ustawodawcę zadań. Według Ustawy o samorządzie gminnym ${ }^{3}$, zadania te w szczególności obejmują sprawy związane z infrastrukturą techniczną i

\footnotetext{
${ }^{1}$ Projekt został sfinansowany ze środków Narodowego Centrum Nauki przyznanych na podstawie decyzji numer DEC-2013/11/D/HS4/03884.

2 Pojęcie „inwestycja” pochodzi od łacińskiego słowa „investio”, oznacza to m.in. osłanianie, ubieranie (Kopaliński W., Słownik wyrazów obcych i zwrotów obcojęzycznych, Wiedza Powszechna, 1990, s.315) nakłady dokonywane $w$ celu stworzenia lub zwiększenia środków trwałych, które przyczyniaja sie do wytworzenia dla przyszlego spożycia strumienia dóbr $i$ uslug 9https://encyklopedia.pwn.pl. Według Filipiak B., Finanse samorzadowe. Narzędzia, decyzje, procesy, Wydawnictwo Naukowe PWN, Warszawa, 2006, s.163, to również finansowe zaangażowanie w przedsięwzięcie, którego celem jest uzyskanie korzyści w przyszłości.

${ }^{3}$ Art. 7 Ustawy z dnia 8 marca 1990r. o samorządzie gminnym (Dz.U. $1990 \mathrm{nr} 16$ poz. 95).
} 
społeczną, ładem przestrzennym oraz ochroną środowiska. O randze szczebla gminnego dla ogólnego rozwoju świadczy również zapis w Konstytucji ${ }^{4}$, że to gmina jest podstawową jednostką samorządu terytorialnego w związku z tym to na niej spoczywa najwięcej potrzeb inwestycyjnych. Władze lokalne chcąc, by dany samorząd terytorialny był silną oraz konkurencyjną jednostka, zobowiązane są do ciagłego podejmowania działań w zakresie inwestycji. Przyczyniają się one do poprawy jakości i ilości obsługiwanych przez samorządy usług społecznych i komunalnych, stąd dzięki nim wzrasta ogólny poziom życia mieszkańców danego samorządu 5 .

Należy podkreślić, że gmina prowadzi działalność non-profit, stąd w przypadku realizowanych przez nią inwestycji, zysk nie jest najważniejszym celem. Często trudno jest wyliczyć także ekonomiczne rezultaty podjętych przedsięwzięć oraz czas zwrotu poniesionych nakładów. Dodatkowo, inwestycje samorządowe, szczególnie w zakresie przedsięwzięć infrastrukturalnych, wiążą się z długim okresem ponoszenia znacznych wydatków inwestycyjnych, a po zrealizowaniu przedsięwzięcia, koniecznością utrzymania inwestycji poprzez ponoszenie zwiększonych wydatków bieżących związanych $\mathrm{z}$ eksploatacją ${ }^{6}$. W związku $\mathrm{z}$ tym władze samorządowe powinny $\mathrm{w}$ racjonalny sposób gospodarować swoimi finansami, a każda jednostka samorządu terytorialnego przed rozpoczęciem planowania inwestycji, powinna szczegółowo ocenić swoją kondycję finansową.

Badanie kondycji finansowej jest trudne, co wynika $\mathrm{z}$ problemu precyzyjnego określenia tego pojęcia ${ }^{7}$. Brak jednolitej definicji związany jest $\mathrm{z}$ podmiotem badania, którego cele funkcjonowania znacznie się różnią. O ile dla osoby fizycznej za istotne należy uznać przede wszystkim wysokość gromadzonych dochodów, skłonność do oszczędzania, to w przypadku przedsiębiorstwa bierze się pod uwagę np. rentowność, płynność finansową i wypłacalność. Z kolei dla jednostki samorządowej istotne są: potencjał dochodowy, samodzielność finansowa, płynność finansowa, zdolności zadłużenia i ich poziom ${ }^{8}$. W dalszej części opracowania uznano je więc za części składowe kondycji finansowej.

\section{Cel główny, material i metody badawcze}

Celem badania było sprawdzenie zależności pomiędzy kondycją finansową a realizacją wydatków inwestycyjnych. Zakres czasowy objął lata 2006-2015. Posłużono się przykładem gmin wiejskich województwa wielkopolskiego. Przyjęto stan gmin w momencie przeprowadzania analiz tzn. 15.10.2017 roku $(N=116)$. $Z$ uwagi na złożony charakter kondycji finansowej, wyrażono ją za pomocą syntetycznego miernika. W tym celu posłużono się metodą TOPSIS. Znalazła ona nieliczne zastosowanie w stosunku do

\footnotetext{
${ }_{4}^{4}$ Art. 164 Konstytucji Rzeczpospolitej Polskiej z dnia 2 kwietnia 1997r. (Dz.U. 1997 nr 78 poz 483).

${ }^{5}$ Górniak R, Sierak J., Ocena efektywności i finansowanie projektów inwestycyjnych jednostek samorządu terytorialnego współfinansowanych funduszami Unii Europejskiej, Oficyna Wydawnicza SGH, Warszawa, 2011, s.25.

6 Misterek W., Zewnętrzne źródła finansowania działalności inwestycyjnej jednostek samorządu terytorialnego, Difin, Warszawa, 2008, s. 35.

7 Satoła Ł., Kondycja finansowa gmin w warunkach zmiennej koniunktury gospodarczej. Journal of Agribusiness and Rural Development. Nr 1(35), 2015.

${ }^{8}$ Standar A., Ocena kondycji finansowej gmin oraz jej wybranych uwarunkowań na przykładzie województwa wielkopolskiego przy wykorzystaniu metody TOPSIS, Wieś i rolnictwo, Kwartalnik Nr 2 (175) 2017.
} 
badania sytuacji finansowej JST. O jej przydatności świadczą badania np. Bieniasz A., Gołaś Z, Łuczak A., ${ }^{9}$ i Standar ${ }^{10}$. Metody porządkowania liniowego, w tym TOPSIS, umożliwiają pomiar wielowymiarowego zjawiska, jak również uprządkowanie badanych obiektów według przyjętych założeń, przez co pozwalają określić ich pozycję ${ }^{11}$.

Konstrukcja syntetycznego miernika składa się z kilku etapów. Po pierwsze, na podstawie merytorycznych przesłanek, dokonano wyboru zmiennych opisujących kondycję finansową gmin. Uwzględniono: udział dochodów bieżących w dochodach ogółem (\%), udział dochodów własnych w dochodach ogółem (\%), udział nadwyżki operacyjnej w dochodach ogółem (\%), udział wydatków majątkowych w wydatkach ogółem (\%), obciążenie wydatków bieżących wydatkami na wynagrodzenia i pochodne (\%), udział nadwyżki operacyjnej i dochodów ze sprzedaży majątku w dochodach ogółem (\%), "wskaźnik samofinansowania" udział nadwyżki operacyjnej i dochodów majątkowych w wydatkach majątkowych (\%), transfery bieżące na mieszkańca (zł), nadwyżka operacyjna na mieszkańca (zł), zobowiązania ogółem na mieszkańca (zł), udział zobowiązań ogółem w dochodach ogółem (\%), obciążenie dochodów ogółem wydatkami na obsługę zadłużenia (\%), obciążenie dochodów własnych wydatkami na obsługę zadłużenia (\%), udział zobowiązań wymagalnych w zobowiązaniach ogółem (\%), suma pozyskanych środków UE na mieszkańca (zł), suma pozyskanych środków UE w dochodach ogółem (\%). Następnie na podstawie statystycznych przesłanek wybrano spośród tego zbioru cechy proste będące wyznacznikami cząstkowymi rozpatrywanego zjawiska. $\mathrm{W}$ tym celu wyeliminowano nadmierne skorelowanie poprzez poddanie analizie elementów diagonalnych macierzy odwrotnej do macierzy korelacji $\mathrm{R}^{12}$. Przeanalizowano również zmienność cech wyrażoną wskaźnikiem zmienności ${ }^{13}$. W rezultacie do dalszych badań przyjęto 6 cech, z których za stymulanty uznano cechy: udział dochodów własnych w dochodach ogółem (\%), udział nadwyżki operacyjnej w dochodach ogółem (\%), udział wydatków majątkowych w wydatkach ogółem (\%), za destymulanty: transfery bieżące na mieszkańca, obciążenie dochodów ogółem wydatkami na obsługę zadłużenia, natomiast "wskaźnik samofinansowania" udział nadwyżki operacyjnej i dochodów majątkowych w wydatkach majątkowych uznano na nominantę. Następnie, zgodnie $\mathrm{z}$ procedurą zaproponowaną przez Wysockiego ${ }^{14}$ ujednolicono wartości cech diagnostycznych. Na podstawie wystandaryzowanych wartości cech prostych obliczono odległości euklidesowe poszczególnych gmin od wzorca $d_{i}^{+}$i antywzorca rozwoju $d_{i}^{-}$. Kolejno, zgodnie z metodą TOPSIS, obliczono wartości syntetycznego miernika kondycji finansowej gmin w oparciu o wzór

\footnotetext{
${ }^{9}$ Bieniasz A., Gołaś Z, Łuczak A., Zastosowanie metody TOPSIS do oceny kondycji finansowej gmin w Polsce w 2010 roku. Zeszyty Teoretyczne Rachunkowości. Tom 70 (126). SKwP. Warszawa, 2013.

10

Standar A., Ocena kondycji finansowej gmin oraz jej wybranych uwarunkowań na przykładzie województwa wielkopolskiego przy wykorzystaniu metody TOPSIS, Wieś i rolnictwo, Kwartalnik Nr 2 (175) 2017.

${ }^{11}$ Strahl D., Metody porządkowania liniowego w ocenie rozwoju regionalnego. W: Strahl D. (red.) Metody oceny rozwoju regionalnego. Wydawnictwo Akademii Ekonomicznej we Wrocławiu. Wrocław, 2006, s. 160.

${ }^{12}$ Jeżeli te elementy $\mathrm{R}^{-1}$ znacznie przekraczają wartość 10 , oznacza to, że elementy są nadmiernie skorelowane, macierz źle uwarunkowana numerycznie i dlatego cechę tę należy usunąć ze zbioru cech.

${ }^{13}$ Wskaźnik zmienności poniżej 10\%.

14 Wysocki F., Metody taksonomiczne w rozpoznawaniu typów ekonomicznych rolnictwa i obszarów wiejskich. Wydawnictwo Uniwersytetu Przyrodniczego w Poznaniu. Poznań, 2010.
} 


$$
q_{i}=\frac{d_{i}^{-}}{d_{i}^{+}+d_{i}^{-}},(i=1,2, . . n)
$$

Miernik syntetyczny przyjął wartości od 0 do 1 . Im wyższa jego wartość, tym korzystniejsza kondycja finansowa gminy. W następnym etapie, wykorzystując średnią arytmetyczną i odchylenie standardowe $\mathrm{z}$ wartości miernika syntetycznego, dokonano uporządkowania liniowego gmin według poziomu kondycji finansowej ${ }^{15}$. Utworzono cztery klasy, gdzie pierwsza oznacza wysoką kondycję finansową, a czwarta niską.

Przyjęto założenie, że wskaźnikiem świadczącym o wielkości przedsięwzięć inwestycyjnych będzie poziom wydatków majątkowych inwestycyjnych na 1 mieszkańca. Z uwagi na fakt, że inwestycje mają charakter zmienny (inwestycja poczyniona $\mathrm{w}$ danym roku może być finansowa przez wiele następnych lat) posłużono się skumulowanym poziomem inwestycji. Zależność pomiędzy poziomem skumulowanych inwestycji a poziomem syntetycznego miernika sprawdzono współczynnikiem korelacji Pearsona. Dodatkowo za pomocą analizy wariancji, zbadano, czy poziom kondycji finansowej wpływa na klasę realizowanych wydatków inwestycyjnych oraz czy klasa wielkości realizowanych inwestycji w sposób statystycznie istotny oddziałuje na wyniki poszczególnych cech (aktywnych i pasywnych) charakteryzujących kondycję finansowa gmin. Zastosowana w tym celu analiza wariancji wyjaśnia, z jakim prawdopodobieństwem wyodrębnione czynniki mogą być powodem różnic między obserwowanymi średnimi grupowymi ${ }^{16}$. Wykorzystanie metod wariancji wymaga sprawdzenia normalności rozkładu. W tym celu posłużono się histogramami oraz testem Shapiro-Wilka. Dla zmiennych: wskaźnik samofinansowania, obciążenie dochodów ogółem wydatkami na obsługę zadłużenia, obciążenia dochodów własnych wydatkami na obsługę zadłużenia oraz udział zobowiązań wymagalnych $\mathrm{w}$ zobowiązaniach ogółem test Shapiro-Wilka doprowadził do odrzucenia hipotezy zerowej o normalności na poziomie istotności $\mathrm{p}=0,05$. W związku z tym $\mathrm{w}$ dalszej części badań posłużono się nieparametrycznym testem ANOVA Kruskala-Wallisa (KW) oraz wartością p dla porównań wielokrotnych. W przypadku pozostałych zmiennych rozkład był normalny w obrębie grup, co pozwoliło zastosować analizę wariancji ANOVA, obliczono test Fishera-Snedecora (F) oraz test post-hoc Tukeya. Poza tym wykorzystano metody: opisowa, porównawczą i wybrane metody statystyki opisowej. Dane ujęto w tabelach, na rysunkach i wykresach ramkawąsy. Materiał źródłowy pochodził z BDL GUS oraz bazy Ministerstwa Finansów Wskaźniki do oceny sytuacji finansowej jednostki samorzqdu terytorialnego.

\section{Wyniki badań}

\section{Poziom wydatków inwestycyjnych realizowanych przez badane gminy}

Wydatki inwestycyjne gmin wiejskich województwa wielkopolskiego w przeliczeniu na mieszkańca charakteryzowały się zmiennością i nie wykazywały

\footnotetext{
${ }^{15}$ Wysocki F., Lira J., Statystyka opisowa. Wydawnictwo Uniwersytetu Przyrodniczego w Poznaniu. Poznań, 2005 .

${ }^{16}$ Szerzej na temat tej metody i testu zob. Stanisz A., Przystępny kurs statystyki z zastosowaniem STATISTICA PL na przykładach z medycyny. Tom 3. Statsoft. Kraków, 2007.
} 
jednoznacznej tendencji (rys. 1). Największy średni poziom wskaźnika odnotowano w 2011 r., po czym wydatki ulegały obniżeniu. Można przypuszczać, że nasilone procesy inwestycyjne mogły być związane z pozyskaniem przez samorządy dotacji unijnych w ramach perspektywy 2007-2013, których rozliczenie przypadało właśnie na lata 20102011. W 2011 r. w stosunku do 2006 roku wzrost wydatków inwestycyjnych wyniósł aż $106 \%$, po czym nastąpił spadek w stosunku do 2015 r. o 44\%. Różnica pomiędzy dwoma skrajnymi momentami czasowymi wyniosła tylko 62 zł na mieszkańca, co oznacza poprawę wskaźnika zaledwie o $16 \%$.

$\mathrm{W}$ badanym okresie odnotowano zjawisko zmniejszania się zróżnicowania $\mathrm{W}$ zakresie realizowanych inwestycji, co świadczyłoby o wyrównywaniu potencjałów inwestycyjnych. Na przykład w latach 2006-2008 współczynnik zmienności wynosił od $89-126 \%$, podczas gdy w latach $2013-2015$ już tylko od $62 \%$ do $67 \%$. W analizowanym czasie wystapiły gminy, których wydatki inwestycyjne per capita wynosiły zaledwie kilka złotych, (np. Tarnówka, Dominowo i Miłosław) podczas gdy dla innych wskaźnik ten kształtował się na kilku tysięcznym poziomie (np. Tarnowo Podgórne, Suchy Las i Komorniki). Warto podkreślić, że najniższy poziom realizowanych przedsięwzięć wzrastał od 5 zł do 88zł per capita, podczas gdy wskaźnik maksymalny malał od 4,3 tys. zł do 1,5 tys. zł per capita. Oznacza to, że wyrównywania się potencjałów inwestycyjnych analizowanych samorządów zachodzi dzięki współistnieniu dwóch zjawisk, z jednej strony zwiększeniu wydatków inwestycyjnych gmin najbiedniejszych, $z$ drugiej ich ograniczeniu przez gminy najbogatsze.

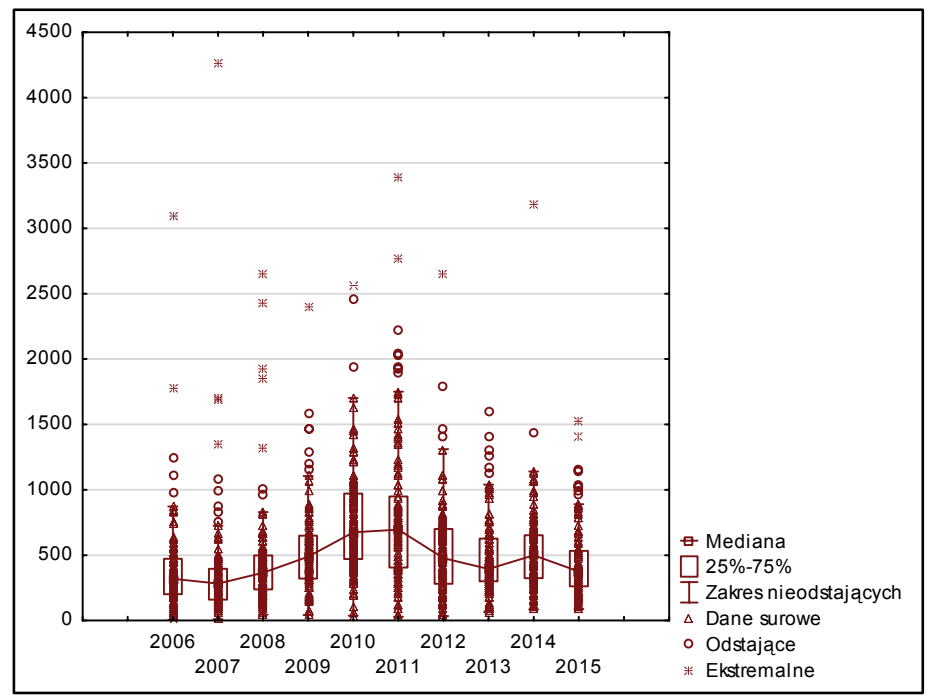

Rysunek 1. Wykres ramka-wąsy dla skumulowanego poziomu wydatków inwestycyjnych per capita gmin wiejskich województwa wielkopolskiego Źródło: opracowanie własne. 


\section{Poziom wydatków inwestycyjnych a syntetyczny poziom kondycji finansowej badanych gmin-analiza porównawcza}

Gminy wiejskie cechujące się najwyższym skumulowanym poziomem wydatków inwestycyjnych na 1 mieszkańca (pow. 7,5 tys. zł) stanowią klasę 1. Jest to 11 jednostek samorządowych, które położone są w bliskim sąsiedztwie największych ośrodków miejskich województwa wielkopolskiego, szczególnie Poznania (rys. 2). Do tych jednostek zaliczyć można Suchy Las, Tarnowo Podgórne i Komorniki. Skumulowane wydatki inwestycyjne w Suchym Lesie wyniosły aż ponad 22 tys. zł, gdy druga pod tym względem gmina odnotowała wynik 13 tys. zł. Najliczniejszą grupą były jednostki cechujące się średnio-wysokim (klasa 2) oraz średnio-niskim poziom realizowanych inwestycji (klasa 3) i było to odpowiednio 32 i 67 gmin. Klasa 2 charakteryzuje się poziomem analizowanego wskaźnika powyżej 5,1 tys. zł, a grupa $3-2,7$ tys. zł. Najmniej liczna klasa 4, o niskim poziomie wdrażanych inwestycji, stanowi zbiorowość tylko 6 gmin. Samorządy te zlokalizowane są peryferyjnie, na obrzeżach województwa, szczególnie w czę́ci wschodniej, na ogół cechują się niskim potencjałem demograficznym i gospodarczym.

$\mathrm{Na}$ rys. 2 zestawiono przestrzenne zróżnicowanie poziomu realizowanych inwestycji z syntetycznym poziomem kondycji finansowej. Biorąc pod uwagę poziom syntetycznego wskaźnika, pierwszą klasę o najkorzystniejszym wyniku stanowiło 20 gmin, dla których miernik wyniósł 0,51 . Podobnie jak w przypadku analizowanego wskaźnika wydatków inwestycyjnych, gminy klasy 1 zlokalizowane są w sąsiedztwie średnich i dużych ośrodków miejskich, w tym przede wszystkim Poznania oraz na terenach o korzystnych warunkach naturalnych biorąc pod uwagę złoża naturalne lub potencjał turystyczny. Do nich zaliczyć można: Komorniki, Baranów czy Tarnowo Podgórne. Z kolei grupę o średnio-wysokim poziomie (klasa 2) tworzy 29 jednostek cechujących się wartością wskaźnika syntetycznego od 0,42. Grupa o średnio-niskim poziomie kondycji (klasa 3) jest najliczniejsza i obejmuje 50 samorządów wiejskich. Natomiast tylko 17 jednostek samorządowych odznacza się średnio-niską kondycją, poniżej poziomu 0,34. Najniższą wartością charakteryzują się Mieleszyn, Chocz i Grzegorzew. Biorąc pod uwage przestrzenne rozmieszczenie analizowanych gmin, zauważyć można, podobnie jak w przypadku wskaźnika wydatków inwestycyjnych, że najniższe wartości cechują jednostki zlokalizowane peryferyjnie. $Z$ uwagi na podobieństwo obu zestawień, zasadne było sprawdzenie zależności. Okazało się wówczas, że pomiędzy poziomem realizowanych wydatków a poziomem kondycji występuje średnia zależność (współczynnik korelacji wyniósł 0,5). 

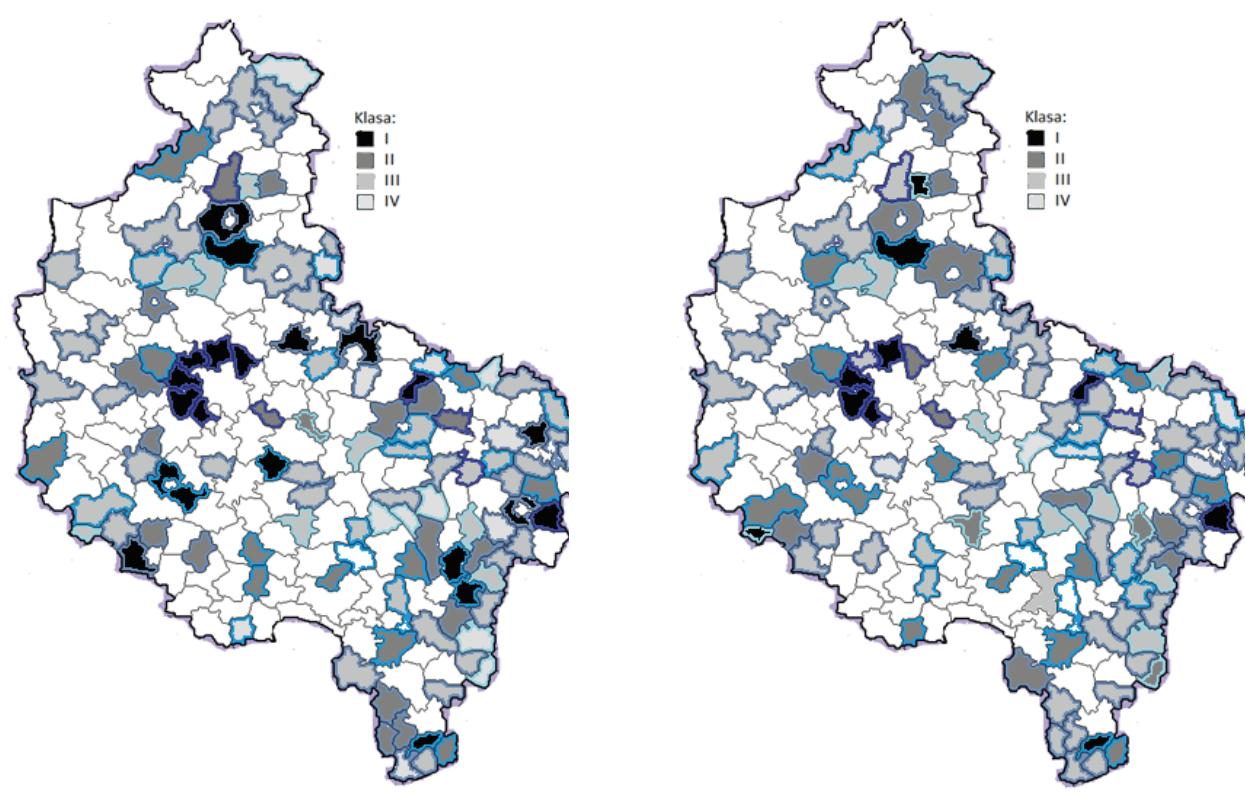

Rysunek 2. Delimitacja gmin wiejskich województwa wielkopolskiego ze względu na poziom kondycji finansowe (po lewej) i skumulowany poziom wydatków inwestycyjnych per capita (po prawej)

Źródło: opracowanie własne.

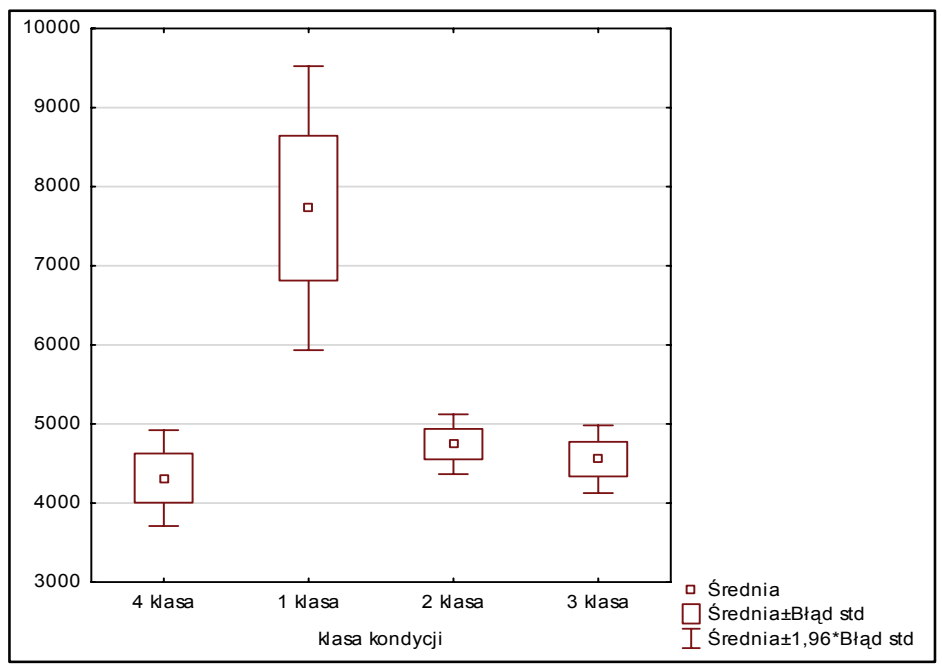

Rysunek 3. Skategoryzowany wykres ramka-wąsy dla średniej skumulowanego poziomu wydatków inwestycyjnych per capita według klasy kondycji finansowej gmin wiejskich województwa wielkopolskiego

Źródło: opracowanie własne. 
Dodatkowo sprawdzono, czy poziom kondycji finansowej w sposób statystycznie istotny wpływa na poziom wdrażanych przedsięwzięć inwestycyjnych. Ze względu na niespełnienie założenia klasycznej analizy wariancji, w zakresie rozkładu normalnego badanej zmiennej w poszczególnych grupach, zastosowano test ANOVA rang KruskalaWallisa. Na podstawie przeprowadzonego testu $\mathrm{KW}=17,91 \mathrm{z}$ prawdopodobieństwem $(\mathrm{p}=0,000)$ odrzucono hipotezę zerową. Na tej podstawie można stwierdzić, że kondycja finansowa istotnie statystycznie wpływa na poziom wydatków inwestycyjnych. W celu uszczegółowienia wniosków wykonano porównanie wielokrotne testu ANOVA rang Kruskala-Wallisa. Na poziomie istotności $(\mathrm{p}<0,05)$ udowodniono istotne statystycznie różnice $\mathrm{w}$ wartości realizowanych inwestycji pomiędzy klasą 1 kondycji finansowej a pozostałymi wyodrębnionymi klasami, co graficznie odzwierciedla skategoryzowany wykres ramka-wąsy (rys. 3). Okazuje się, że im poziom kondycji finansowej wyższy tym wyższy poziom realizowanych inwestycji. W gminach klasy $1 \mathrm{w}$ całym okresie badawczym na cele inwestycyjne przeznaczono średnio 7,7 tys. zł per capita, podczas gdy w gminach cechujących się średnio-wysokim poziomem kondycji 4,7 tys. zł, średnio-niskim 4,5 tys. zł oraz niskim 4,3 tys. zł.

\section{Wydatki inwestycyjne w badanych gminach a skladowe syntetycznego wskaźnika kondycji finansowej}

Spośród wszystkich analizowanych cech kształtujących kondycję finansową w przypadku zaledwie dwóch: wskaźnik samofinansowania oraz udział zobowiązań wymagalnych w zobowiązaniach ogółem, klasa realizowanych wydatków inwestycyjnych nie różniła statystycznie istotnie ich poziomu (tab.1). Oznacza to, że poziom płynności finansowej czy też terminowej spłaty zobowiązań nie jest związany ze skalą podejmowanych przedsięwzięć inwestycyjnych w badanych gminach. Wynik ten należy uznać za dosyć zaskakujący.

Pozostałe cechy, zarówno aktywne jak i pasywne cechowały się statystycznie istotnym zróżnicowaniem $\mathrm{w}$ zależności od poziomu realizowanych inwestycji. Im wyższy poziom samodzielności finansowej (udział dochodów własnych w dochodach ogółem) i nadwyżki operacyjnej (udział nadwyżki operacyjnej w dochodach ogółem, udział nadwyżki operacyjnej i dochodów ze sprzedaży majątku w dochodach ogółem, nadwyżka operacyjna na mieszkańca), tym poziom realizowanych inwestycji jest wyższy. Wysoka samodzielność finansowa świadczy o bogactwie gminy i o uniezależnieniu od budżetu państwa, co sprawia, że nie tylko władzom takich gmin łatwiej zagwarantować środki na realizację wydatków o charakterze inwestycyjnym ale także mają większą swobodę podejmowania decyzji w tym zakresie. Z kolei wysoki poziom nadwyżki operacyjnej oznacza bezpośrednio wysokie możliwości inwestycyjne ale także pośrednio możliwość spłaty wcześniej zaciagniętych zobowiązań. Obecnie średnia tego wskaźnika $z$ trzech lat warunkuje też zdolność zadłużania się. Nie jest to więc zaskakujące, że im te możliwości wyższe, tym więcej środków może być przeznaczane na przedsięwzięcia inwestycyjne.

Biorąc pod uwage cechę pasywną związaną z dochodami - udział dochodów bieżących w dochodach ogółem, potencjał inwestycyjny jest statystycznie wyższy w gminach, gdzie odnotowano niższy poziom tego wskaźnika, co związane jest z faktem, że w gminach proinwestycyjnych pozyskuje się większe dotacje na inwestycje, stąd wspomniany udział dochodów bieżących w ogóle dochodów musi być niższy 
Powyższy wniosek potwierdzają wyniki wpływu klasy realizowanych inwestycji na cechy: suma środków UE na mieszkańca i suma środków UE w dochodach ogółem. Im więcej władzom gmin udało się pozyskać pomocy z UE, tym bardziej kapitałochłonne przedsięwzięcia były wrażane na terenie analizowanych jednostek.

Uwzględniając pozostałe wpływy do gminnego budżetu, transfery bieżące na mieszkańca ulegają obniżeniu wraz z klasą realizowanych inwestycji. Na transfery bieżące składają się subwencja ogólna i dotacje na cele bieżące, a znaczna ich część rozdysponowywana jest zgodnie $\mathrm{z}$ zasadami preferencji jednostek biedniejszych i okazuje się, że nawet w tych gminach, gdzie pomoc państwa jest najwyższa, potencjał inwestycyjny kształtuje się na niższym poziomie. W związku z tym można stwierdzić, że o wielkości realizowanych inwestycji nie świadczy skala pomocy państwa a potencjał własny jednostek. 


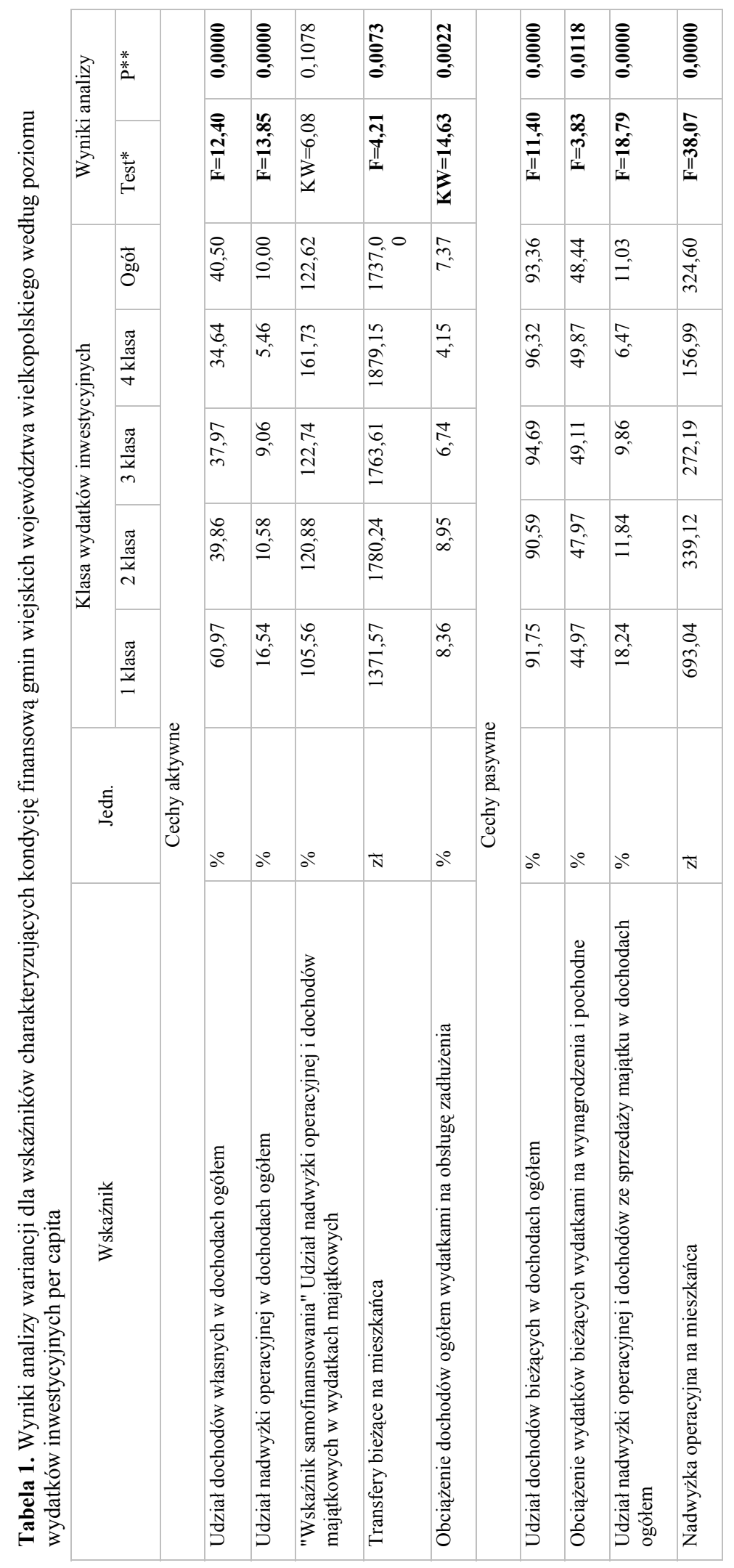




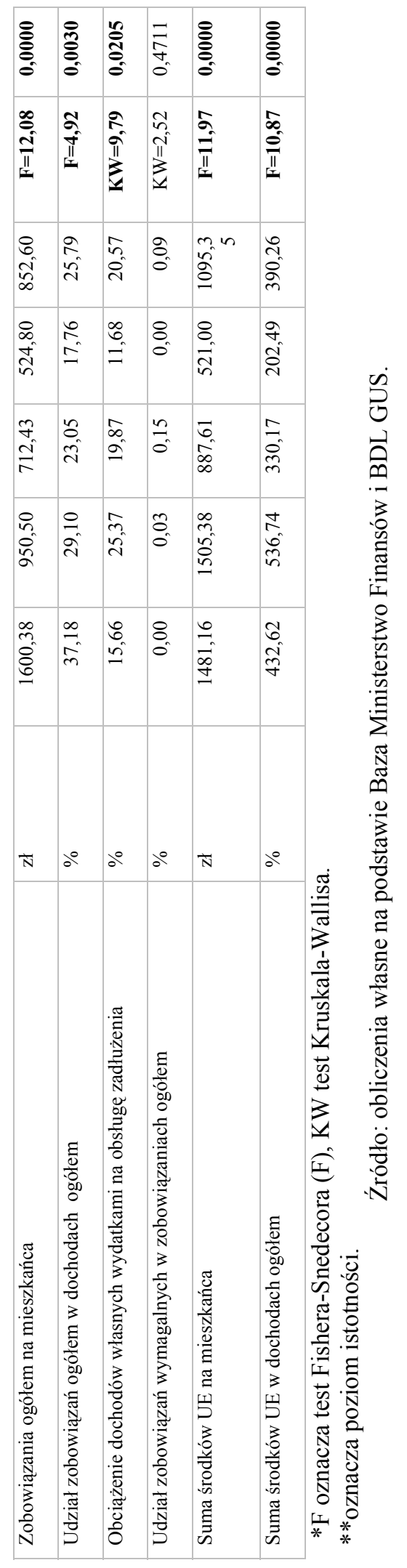


Tam, gdzie władze gmin przeznaczają większe środki na inwestycje, lepiej zarządzają również wydatkami przeznaczając ich stosunkowo mniej na wydatki osobowe. Co się tyczy zadłużenia, jego obsługa jest średnio istotnie wyższa w gminach o znacznych nakładach inwestycyjnych, co związane jest z potrzebą wykorzystywania w tych jednostkach różnych źródeł finansowania inwestycji, w tym także o charakterze zwrotnym. O tym, że w relatywnie większym stopniu z zobowiązań korzystano w jednostkach proinwestycyjnych, świadczą też takie pasywne wskaźniki, jak: zobowiązania ogółem na mieszkańca i udział zobowiązań ogółem w dochodach ogółem. Poziomy obu wprost proporcjonalnie zwiększają się wraz z klasą wydawanych środków na inwestycje.

\section{Podsumowanie i wnioski}

Celem badania było sprawdzenie zależności pomiędzy kondycją finansową a realizacją wydatków inwestycyjnych na przykładzie gmin wiejskich województwa wielkopolskiego. W wyniku przeprowadzonych analiz sformułowano następujące wnioski:

1. Wydatki inwestycyjne analizowanej grupy samorządów w przeliczeniu na mieszkańca charakteryzowały się znacznymi wahaniami i nie wykazywały jednoznacznej tendencji. Do roku 2011 r. poziom wskaźnika wzrastał, po czym uległ obniżeniu. Można przypuszczać, że nasilone procesy inwestycyjne $\mathrm{w}$ pierwszej cześci okresu badawczego mogły być związane z pozyskaniem przez samorządy dotacji unijnych $w$ ramach perspektywy 2007-2013.

2. Badane gminy charakteryzowały się znacznym zróżnicowaniem przeznaczanych środków na inwestycje, które systematycznie malało. Do najbardziej proinwestycyjnych samorządów należy zaliczyć duże jednostki, zlokalizowane w otoczeniu dużych ośrodków miejskich, w szczególności Poznania. Natomiast najmniej na inwestycje wydaje się $w$ jednostkach położonych peryferyjnie, na ogół we wschodniej części województwa.

3. Z uwagi na podobieństwo przestrzennego zróżnicowania wydatków inwestycyjnych per capita jak i kondycji finansowej, zasadnym było sprawdzenie tej zależności, która okazała się średnia (współczynnik korelacji wyniósł 0,5). Dodatkowo, na podstawie przeprowadzonego testu KruskalaWallisa można stwierdzić, że klasa kondycji finansowej istotnie statystycznie oddziałuje na poziom wydatków inwestycyjnych. Na ten wynik wpłynęły różnice $\mathrm{w}$ wartości realizowanych inwestycji pomiędzy klasą 1 kondycji finansowej a pozostałymi wyodrębnionymi grupami. Generalnie, im wyższa klasa kondycji finansowej, tym wyższy poziom realizowanych inwestycji.

4. Spośród wszystkich analizowanych cech kształtujących kondycję finansową w przypadku zaledwie dwóch, klasa realizowanych wydatków inwestycyjnych nie różniła statystycznie istotnie ich wielkości. Poziom wydatków inwestycyjnych wzrasta wraz ze wzrostem m.in.: dochodów własnych, pozyskanych środków z UE, nadwyżki operacyjnej, ale również zadłużenia i jego obsługi. Zależność jest odwrotnie proporcjonalna biorąc pod uwage, np. transfery z budżetu i wydatki na wynagrodzenia i pochodne. 


\section{Bibliografia}

Bieniasz A., Gołaś Z, Łuczak A., Zastosowanie metody TOPSIS do oceny kondycji finansowej gmin w Polsce w 2010 roku. Zeszyty Teoretyczne Rachunkowości. Tom 70 (126). SKwP. Warszawa, 2013.

Filipiak B., Finanse samorządowe. Narzędzia, decyzje, procesy, Wydawnictwo Naukowe PWN, Warszawa, 2006.

Górniak R, Sierak J., Ocena efektywności i finansowanie projektów inwestycyjnych jednostek samorządu terytorialnego współfinansowanych funduszami Unii Europejskiej, Oficyna Wydawnicza SGH, Warszawa, 2011.

https://encyklopedia.pwn.pl, dostęp 21.10.2017.

Konstytucja Rzeczpospolitej Polskiej z dnia 2 kwietnia 1997r. [Dz.U. 1997 nr 78 poz 483]

Kopaliński W., Słownik wyrazów obcych i zwrotów obcojęzycznych, Wiedza Powszechna, 1990.

Misterek W., Zewnętrzne źródła finansowania działalności inwestycyjnej jednostek samorządu terytorialnego, Difin, Warszawa, 2008.

Satoła Ł., Kondycja finansowa gmin w warunkach zmiennej koniunktury gospodarczej. Journal of Agribusiness and Rural Development. Nr 1(35), 2015.

Standar A., Ocena kondycji finansowej gmin oraz jej wybranych uwarunkowań na przykładzie województwa wielkopolskiego przy wykorzystaniu metody TOPSIS, Wieś i rolnictwo, Kwartalnik Nr 2 (175) 2017

Stanisz A., Przystępny kurs statystyki z zastosowaniem STATISTICA PL na przykładach z medycyny. Tom 3. Statsoft. Kraków, 2007.

Strahl D., Metody porządkowania liniowego w ocenie rozwoju regionalnego. W: Strahl D. (red.) Metody oceny rozwoju regionalnego. Wydawnictwo Akademii Ekonomicznej we Wrocławiu. Wrocław, 2006.

Ustawa z dnia 8 marca 1990r. o samorządzie gminnym [Dz.U. $1990 \mathrm{nr} 16$ poz. 95].

Wskaźniki do oceny sytuacji finansowej jednostki samorządu terytorialnego w latach 2012-2014, Ministerstwo Finansów, Warszawa, 2014, http.//www.mf.gov.pl, dostęp 21.07.2017.

Wysocki F., Lira J., Statystyka opisowa. Wydawnictwo Uniwersytetu Przyrodniczego w Poznaniu. Poznań, 2005.

Wysocki F., Metody taksonomiczne w rozpoznawaniu typów ekonomicznych rolnictwa i obszarów wiejskich. Wydawnictwo Uniwersytetu Przyrodniczego w Poznaniu. Poznań, 2010.

\section{Summary}

The aim of the study was to examine the relationship between financial condition and the implementation of investment expenditures on the example of rural communes of the Wielkopolska province. The first part presents the development of the investment expenditure per capita by means of the descriptive statistics. Subsequently, the communes was grouped according to the surveyed measure and compared with the synthetic financial condition measure. The correlation between these measures was examined successively and the result of its occurrence became the basis for deepening the analysis. It was found that the communes with the most favorable financial situation achieved the largest investments, the result of which was statistically significantly higher than the other groups of local government units. In the last part it was proved that the mentioned dependency also occurs between the analyzed investment expenditure index and the financial variables giving the financial condition of communes. 
Key words: variance analysis, local governments, TOPSIS method, investment expenditures.

Informacja o autorze:

\section{dr Aldona Standar}

Uniwersytet Przyrodniczy w Poznaniu,

Wydział Ekonomiczno-Społeczny,

Katedra Ekonomii i Polityki Gospodarczej w Agrobiznesie,

ul. Wojska Polskiego 28,

60-637 Poznań

e-mail: standar@up.poznan.pl. 